\title{
ANALISIS JARINGAN KOMUNIKASI KELOMPOK TANI DALAM PENERAPAN BUDI DAYA PADI METODE SYSTEM OF RICE INTENSIFICATION (SRI)
}

\section{ANALYSIS OF FARMERS' COMMUNICATION NETWORK IN THE IMPLEMENTATION OF SYSTEM OF RICE INTENSIFICATION (SRI)}

\author{
Nadia Itona Siregar ${ }^{1}$, Dwi Sadono², Cahyono Tri Wibowo ${ }^{3}$ \\ ${ }^{1}$ Program Studi Komunikasi Pembangunan Pertanian dan Pedesaan \\ Sekolah Pascasarjana, Institut Pertanian Bogor \\ ${ }^{2}$ Departemen Sains Komunikasi dan Pengembangan Masyarakat FEMA IPB \\ ${ }^{3}$ Pascasarjana Komunikasi Pembangunan Pertanian dan Pedesaan, IPB \\ Jln. Kamper, Kampus IPB Dramaga Bogor Indonesia \\ nadiasiregar.kpm48@gmail.com
}

Diterima : 30 April 2019

Direvisi : 25 Mei 2019

Disetujui : 19 November 2019

\begin{abstract}
Agricultural activities rely heavily on information. Study of information flow, relations among individuals, and interaction patterns in farmer groups related to rice cultivation using SRI method can be performed using communication network analysis. The objectives of this study were: (1) to analyze the communication network structure in farmer groups, (2) to analyze the relationship between communication networks and the application of SRI method of rice cultivation. This research was conducted at Sekar Arum and Sumber Urip farmer groups in Banyuwangi. This study involved 74 respondents. This study used intact system sampling method, which included all individuals in the system as samples. To collect data, this study used free recall method, which formulated questions in a questionnaire with a list of names. This study used Pearson Correlation Test as data analysis technique. The results showed that: (1) The structure of the communication network formed in the two farmer groups was interlocking personal network and star, (2) there was a correlation between out-degree centrality and closeness with the application of SRI method of rice cultivation.
\end{abstract}

Keywords: Communication Network Analysis, Communication Network Structure, System Of Rice Intensification (SRI)

\begin{abstract}
ABSTRAK
Kegiatan pertanian sangat bergantung dengan informasi dalam berbagai bentuk. Kajian terkait dengan arus informasi, hubungan relasi antarindividu, dan pola interaksi dalam kelompok tani yang terkait dengan budi daya padi metode system of rice intensification (SRI) dapat dilakukan dengan menggunakan analisis jaringan komunikasi. Tujuan dari penelitian ini adalah: (1) untuk menganalisis struktur jaringan komunikasi dalam kelompok tani, (2) untuk menganalisis hubungan antara jaringan komunikasi dengan penerapan budi daya padi metode SRI. Penelitian ini dilakukan pada kelompok tani Sekar Arum dan kelompok tani Sumber Urip di Banyuwangi. Penelitian ini memiliki 74 responden. Teknik pengambilan sampel menggunakan metode intact sampling, yaitu mengambil seluruh individu yang termasuk di dalam sistem sebagai sampel. Pengumpulan data dalam penelitian ini menggunakan free recall method yaitu metode analisis jaringan komunikasi, yang merumuskan pertanyaan dalam kuesioner dengan daftar nama. Analisis data menggunakan uji korelasi Pearson. Hasil penelitian menunjukkan bahwa: (1) struktur jaringan komunikasi yang terbentuk pada dua kelompok tani adalah interlocking network dan star, (2) terdapat korelasi positif antara out-degree centrality dan closeness dengan penerapan budi daya padi metode SRI.
\end{abstract}

Kata Kunci: Analisis Jaringan Komunikasi, Struktur Jaringan Komunikasi, Metode System Of Rice Intensification (SRI) 


\section{PENDAHULUAN}

Pertanian merupakan salah satu sektor penting dalam pembangunan ekonomi Indonesia. Peningkatan pertumbuhan sektor pertanian akan menciptakan ketahanan pangan bagi negara Indonesia. Hal ini juga menjadi salah satu solusi terhadap permasalahan sosial seperti masalah kemiskinan dan ketidakmerataan kesejahteraan. Fokus pemerintah terhadap masalah ini dapat dilihat di Nawacita, yakni sembilan agenda prioritas pembangunan Presiden Joko Widodo. Salah satunya adalah peningkatan produktivitas dan daya saing di pasar internasional. Di dalam agenda tersebut, terdapat sub agenda peningkatan kedaulatan pangan, yang salah satu sasarannya adalah "Pengembangan 1000 Desa Pertanian Organik”. Sektor pertanian saat ini hanya mampu menyumbang 13,59\% terhadap pertumbuhan ekonomi pada triwulanI tahun 2017. Pada triwulan II 2017 hanya terjadi peningkatan sebesar $0,33 \%$ sehingga angka totalnya mencapai $13,92 \%$ (Kementan RI, n.d.). Kurang maksimalnya kontribusi sektor pertanian terhadap pertumbuhan ekonomi saat ini disebabkan oleh beberapa faktor.

Permasalahan mendasar yang dihadapi sektor pertanian, khususnya pada kurun waktu 2015-2019, mencakup aspek kerusakan lingkungan dan perubahan iklim serta permasalahan kelembagaan dan sumber daya manusia (Kementan RI, 2015). Isu kerusakan lingkungan adalah salah satu permasalahan mendasar yang memerlukan perubahan pola pikir dan perilaku bertani rakyat Indonesia. Luas lahan kritis di Indonesia saat ini mencapai 14 juta hektar (Mediani, 2018). Sumber lain menyebut bahwa $69 \%$ tanah Indonesia tergolong rusak parah dan hal ini disebabkan oleh penggunaan pupuk dan pestisida yang berlebihan (Fitrianto, 2018). Di samping itu, terjadinya perubahan iklim sebagai akibat dari pemanasan global juga berdampak luas terhadap berbagai aspek kehidupan termasuk sektor pertanian. Dampak dari perubahan iklim adalah bergesernya pola dan kalender tanam, perubahan keanekaragaman hayati, eksplosi hama dan penyakit tanaman dan hewan, yang pada akhirnya bermuara pada penurunan produksi pertanian (Kementan RI, 2015).

Pelaku sektor pertanian dituntut untuk melakukan perubahan paradigma dari sistem pertanian konvensional ke sistem pertanian bioindustri berkelanjutan. Perubahan paradigma tersebut mendorong petani untuk meningkatkan kesuburan dan produktivitas lahan sehingga penggunaan pupuk kimia selama proses pertanian sebisa mungkin dihindarkan. Hal inilah yang kemudian mendorong munculnya program pengembangan pertanian ramah lingkungan, yang salah satunya dikenal sebagai system of rice intensification (SRI). Selama tahun 20112013, luas areal yang berhasil dikembangkan melalui pendekatan SRI meningkat dari 10.440 hektar menjadi 205.450 hektar dengan realisasi program di atas 93\% (Kementan RI, 2015). Salah satu daerah yang turut mengembangkan budi daya padi dengan metode SRI adalah Kabupaten Banyuwangi. Budi daya padi dengan metode SRI masih tergolong baru di kalangan petani. Terkait hal ini, Rogers (1983) menyatakan bahwa jika suatu gagasan itu tampak baru bagi individu, hal itu disebut inovasi. Menurut Anugrah, Sumedi, dan Wardana (2008), SRI merupakan salah satu pendekatan dalam praktik budi daya padi yang menekankan pada manajemen pengelolaan tanah, tanaman dan air melalui pemberdayaan kelompok dan kearifan lokal yang berbasis pada kegiatan ramah lingkungan. 
Terdapat beberapa perbedaan mendasar dalam budi daya padi konvensional dengan yang menggunakan metode SRI. Perbedaan tersebut mencakup pengujian benih dengan larutan garam, penggunaan bibit yang berumur 5-15 hari, pengolahan tanah menggunakan bahan organik, pengaturan jarak tanam padi antara $25 \times 25 \mathrm{~cm}$ atau $30 \times 30 \mathrm{~cm}$, pemberian satu bibit per lubang tanam, pengaturan cara tanam akar berbentuk "L" dengan kedalaman 1-1,5 cm, pengaturan kondisi lahan tanam agar senantiasa becek, serta pengendalian hama dan gulma yang tidak menggunakan pestisida dan kimia lainnya.

Dalam merespon sebuah cara tanam baru, petani dihadapkan pada proses pengambilan keputusan. Proses pengambilan keputusan untuk menerima suatu inovasi berlangsung ketika seorang individu menggunakan pengetahuan pertamanya tentang inovasi untuk membentuk sikap terhadap inovasi tersebut, keputusan untuk mengadopsi atau menolak, untuk menerapkan ide baru, dan untuk mengonfirmasi keputusan tersebut (Rogers, 1983). Tahap pengambilan keputusan selalu melibatkan dua pilihan, yaitu adopsi (penerapan) dan penolakan. Menurut Soekartawi (2005), hal yang sangat memengaruhi proses adopsi inovasi adalah sumber informasi. Dalam hal ini, sumber informasi terpenting adalah teman atau tetangga, pengamatan pribadi, agen pertanian, media massa, dan pedagang. Jadi, sosialisasi dan penyebaran informasi tentang metode SRI akan lebih efektif dan efisien bila dilakukan ke lembaga pertanian, misalnya kelompok tani.

Masalahnya, kelompok tani yang ada saat ini lebih merupakan organisasi sosial budaya, yang sebagian besarnya dibentuk hanya untuk mendapatkan fasilitas pemerintah seperti bantuan dan subsidi pupuk (Kementan RI,
2015). Hal inilah yang menyebabkan kelompok tani belum dapat sepenuhnya memanfaatkan peluang akses terhadap informasi teknologi, permodalan dan pasar untuk mengembangkan usaha pertanian. Penyebaran informasi di dalam kelompok tani tidak terlepas dari proses komunikasi dan pola interaksi yang terjadi di dalam kelompok. Hal ini selaras dengan hasil penelitian yang dilakukan oleh Adawiyah, Sumardjo, dan Mulyani (2017) yang menunjukkan bahwa salah satu faktor yang memengaruhi tingkat adopsi inovasi teknologi adalah peran komunikasi kelompok tani.

Pola interaksi dipengaruhi oleh kecenderungan anggota untuk berkomunikasi satu sama lain. Selain itu, status dan relasi kuasa dalam kelompok juga memengaruhi pola interaksi. Daya tarik personal, ikatan emosional dan kesamaan minat di antara beberapa anggota lebih kuat daripada anggota lainnya. Hal ini menyebabkan terbentuknya subkelompok, baik yang terdiri dari dua orang (dyadic group) maupun tiga orang (triadic group). Bahkan ada pula anggota kelompok yang terisolasi sehingga penyebaran informasi dan inovasi menjadi tidak merata di seluruh anggota kelompok (Toesland, Jones, \& Gellis, 2004). Dalam hal ini, penguatan jaringan kelompok tani sangat ditentukan oleh eratnya jalinan jaringan komunikasi antaranggota kelompok tani maupun antarkelompok tani. Studi mengenai arus informasi, hubungan relasi antarindividu dan pola interaksi dalam kelompok dapat dilakukan dengan menggunakan analisis jaringan komunikasi.

Menurut Rogers dan Kincaid (1981), analisis jaringan komunikasi adalah metode penelitian untuk komunikasi dalam sistem. Aliran komunikasi dianalisis menggunakan beberapa tipe hubungan interpersonal sebagai unit analisis. Jaringan komunikasi merupakan 
model dari komunikasi konvergen sehingga tidak jauh berbeda dengan model komunikasi konvergen. Dalam hal ini, jumlah unit analisis jaringan komunikasi ada lima, yaitu individu, jaringan komunikasi personal, hubungan diadik, klik, dan sistem (jaringan) (Rogers \& Kincaid, 1981).

Definisi lain dikemukakan oleh Monge dan Contractor (2003), yang menjelaskan bahwa jaringan komunikasi adalah pola kontak yang diciptakan oleh arus pesan dari komunikator melalui ruang dan waktu. Konsep pesan harus dipahami dalam arti luas menyangkut data, informasi, pengetahuan, gambar, simbol, dan bentuk lainnya yang dapat berpindah dari satu titik ke jaringan lain atau dapat dikoordinasikan oleh anggota jaringan. Tidak jauh berbeda dengan Rogers dan Kincaid (1981), menurut Monge dan Contractor (2003), unit analisis dalam jaringan komunikasi terbagi menjadi lima level yaitu level individu, level dua orang, level tiga orang, level subkelompok, dan level jaringan global. Selanjutnya, menurut Gunawan (2017), jaringan komunikasi adalah saluran dari aliran pesan yang terbentuk sesuai kebutuhan kelompok atau organisasi serta anggota di dalamnya. Berdasarkan beberapa definisi tersebut dapat disimpulkan bahwa jaringan komunikasi adalah pola kontak yang tercipta antarindividu dalam suatu kelompok atau organisasi yang dapat diidentifikasikan sebagai pertukaran pesan dengan pola tertentu. Pada penelitian ini, pembahasan analisis jaringan komunikasi difokuskan pada unit individu dengan melihat in-degree centrality, out-degree centrality, kedekatan (closeness), dan betweenness centrality.

Terdapat sejumlah studi tentang analisis jaringan komunikasi yang memperlihatkan bahwa jaringan komunikasi yang terbentuk dalam suatu kelompok memengaruhi proses penyebaran informasi dan adopsi inovasi. Penelitian yang dilakukan oleh Cindoswari (2012) menunjukkan bahwa petani ubi kayu yang terlibat dalam jaringan komunikasi dan memiliki kemampuan untuk menghubungi petani ubi kayu lain merupakan petani yang menerapkan teknologi produksi paling maju. Hasil penelitian yang dilakukan oleh Hertanto, Sugiyanto, dan Safitri (2016) juga menunjukkan bahwa terdapat hubungan yang nyata dan positif antara jaringan komunikasi dengan penerapan teknologi budi daya kentang. Hal ini menunjukkan pentingnya jaringan komunikasi kelompok tani dalam proses adopsi inovasi. Sekalipun demikian, tidak banyak studi tentang jaringan komunikasi asimetris yang terkait dengan penerapan teknologi khususnya budidaya padi metode SRI.

Penerapan inovasi dalam kelompok secara efektif mengharuskan setiap anggota untuk dapat berkomunikasi dengan mudah dan efisien. Akan tetapi, pola komunikasi yang tercipta dipengaruhi oleh kecenderungan anggota untuk berkomunikasi satu sama lain. Kecenderungan ini ditentukan oleh daya tarik personal, ikatan emosional, dan kesamaan minat sehingga tidak jarang terdapat subkelompok di dalam kelompok, bahkan ada anggota yang terisolasi. Pentingnya perubahan paradigma dari sistem pertanian konvensional ke sistem pertanian bioindustri berkelanjutan mendorong kelompok tani untuk mengaplikasikan budi daya padi metode SRI dengan baik dan berkelanjutan. Akan tetapi, kesuksesan suatu inovasi dipengaruhi juga oleh kelancaran arus informasi, pembentukan pola komunikasi, dan aktor yang menjadi sumber informasi. Berdasarkan uraian di atas, maka penulis tertarik untuk meneliti jaringan komunikasi pada kelompok tani yang sudah menerapkan budi daya padi metode SRI. 
Terkait dengan hal tersebut, penulis akan menganalisis struktur jaringan komunikasi dalam kelompok tani dan menganalisis hubungan antara jaringan komunikasi dengan penerapan budi daya padi metode SRI. Hasil penelitian ini diharapkan dapat memberikan manfaat kepada para pemangku kepentingan dalam merumuskan strategi pengembangan budi daya padi dengan metode SRI berbasis kearifan lokal.

\section{METODOLOGI PENELITIAN}

Penelitian ini bersifat deskriptif korelasional. Lokasi penelitian berada di Desa Watukebo, Kecamatan Rogojampi dan di Desa Sumber Agung, Kecamatan Pesanggaran, Kabupaten Banyuwangi dengan subjek penelitian yaitu kelompok tani Sumber Urip dan kelompok tani Sekar Arum. Pemilihan lokasi penelitian dilakukan secara purposive. Pengumpulan data dilakukan pada bulan MeiJuni 2018. Penentuan responden dalam penelitian ini menggunakan metode intact sampling, yaitu mengambil seluruh individu di dalam sistem sebagai sampel. Jumlah responden dalam penelitian ini adalah sebanyak 27 orang dari kelompok tani Sekar Arum dan 47 orang dari kelompok tani Sumber Urip. Pengumpulan data dalam jaringan komunikasi ini menggunakan free recall method yaitu metode analisis jaringan komunikasi yang merumuskan pertanyaan dalam kuesioner dengan daftar nama.

Data primer diperoleh dari responden dengan menggunakan teknik wawancara menggunakan kuesioner dan observasi langsung. Adapun data sekunder diperoleh dari data potensi desa, jurnal penelitian, tesis, dan tulisan-tulisan ilmiah terkait dengan penelitian ini. Analisis sosiometri menggunakan perangkat lunak UCINET VI untuk menggambarkan pola komunikasi antarindividu di dalam kelompok tani. Analisis data secara statistik deskriptif dilakukan dengan menggunakan tabel frekuensi, persentase, dan gambar. Adapun analisis data secara statistik inferensial dilakukan dengan menggunakan uji korelasi Pearson untuk melihat hubungan antarvariabel dengan bantuan program IBM SPSS Statistics 22.

\section{HASIL DAN PEMBAHASAN}

Jaringan komunikasi adalah pola kontak yang tercipta antarindividu dalam suatu kelompok atau organisasi yang dapat diidentifikasikan sebagai pertukaran pesan dengan pola tertentu. Jaringan komunikasi diukur melalui indikator sentralitas (centrality), kedekatan (closeness), dan betweenness. Analisis jaringan komunikasi pada penelitian ini mengidentifikasi struktur jaringan komunikasi dan mengukur berbagai indeks jaringan komunikasi pada level unit individu seperti in-degree centrality, out-degree centrality, kedekatan (closeness), dan betweenness.

Identifikasi struktur jaringan komunikasi dilakukan dengan analisis sosiometri. Analisis sosiometri digunakan untuk menggambarkan data kuantitatif mengenai pola komunikasi antarindividu dalam sistem. Analisis sosiometri disajikan dalam bentuk sosiogram dan dianalisis dengan perangkat lunak UCINET VI.

Sebagaimana dijelaskan sebelumnya, dalam penelitian ini akan dilakukan analisis terhadap dua kelompok tani dengan karakteristik yang sama. Kelompok pertama adalah kelompok tani Sumber Urip yang beranggotakan 47 anggota petani padi dengan metode SRI, sedangkan kelompok kedua adalah kelompok tani Sekar Arum yang beranggotakan 27 petani padi dengan metode 
SRI. Sebelum melakukan analisis sosiometri, terlebih dahulu setiap anggota di kedua kelompok tani tersebut diberikan kode berupa angka yang berkisar antara 1-74. Kode masingmasing individu dapat dilihat pada Tabel 1 .

Tabel 1. Kode Anggota Kelompok Tani dalam Jaringan Komunikasi di Kedua Kelompok Tani

\begin{tabular}{cccc}
\hline No & Nama Kelompok Tani & Jumlah Anggota (orang) & Kode Anggota \\
\hline 1. & Sekar Arum & 27 & $1,2,3,4,5,6,7,8,9,10,11,12,13,14,15,16$, \\
& & & $17,18,19,20,21,22,23,24,25,26,27$ \\
2. & Sumber Urip & 47 & $28,29,30,31,32,33,34,35,36,37,38,39,40$, \\
& & & $41,42,43,44,45,46,47,48,49,50,51,52,53$, \\
& & $54,55,56,57,58,59,60,61,62,63,64,65,66$, \\
\end{tabular}

Analisis jaringan komunikasi pada kedua kelompok tani ini dikhususkan pada pertukaran pesan atau penyebaran informasi yang terkait dengan budi daya padi metode SRI. Sosiogram pada kelompok tani Sekar Arum dapat dilihat pada Gambar 1, sedangkan sosiogram pada kelompok tani Sumber Urip dapat dilihat pada Gambar 2. Berdasarkan pola kontak yang terbentuk pada Gambar 1 dan 2, terlihat bahwa struktur jaringan komunikasi yang terbentuk cenderung bersifat memusat. Sebagaimana terlihat pada gambar tersebut, terdapat beberapa aktor sentral dan setiap anggota saling berinteraksi satu sama lain mengenai cara budi daya dan berbagi informasi mengenai solusi yang berkaitan dengan budi daya padi dengan metode SRI.

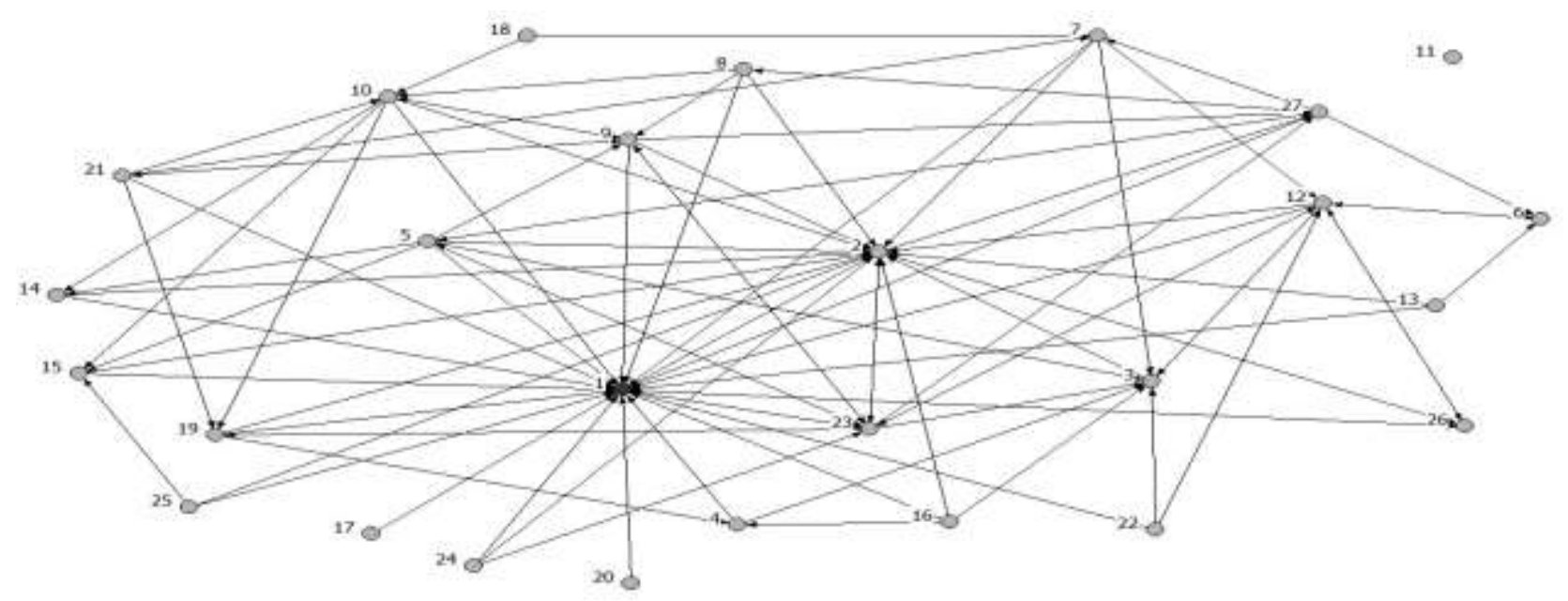

Gambar 1. Sosiogram Analisis Jaringan Komunikasi dalam Teknik Budi Daya Padi dengan Metode SRI pada Kelompok Tani Sekar Arum di Banyuwangi, 2018 
Gambar 1 memperlihatkan aktor sentral dalam kelompok (aktor 1) yaitu Bapak NYO. Bapak NYO merupakan ketua kelompok tani
Sekar Arum yang cukup sukses dalam menerapkan budi daya padi metode SRI di antara anggota lainnya.

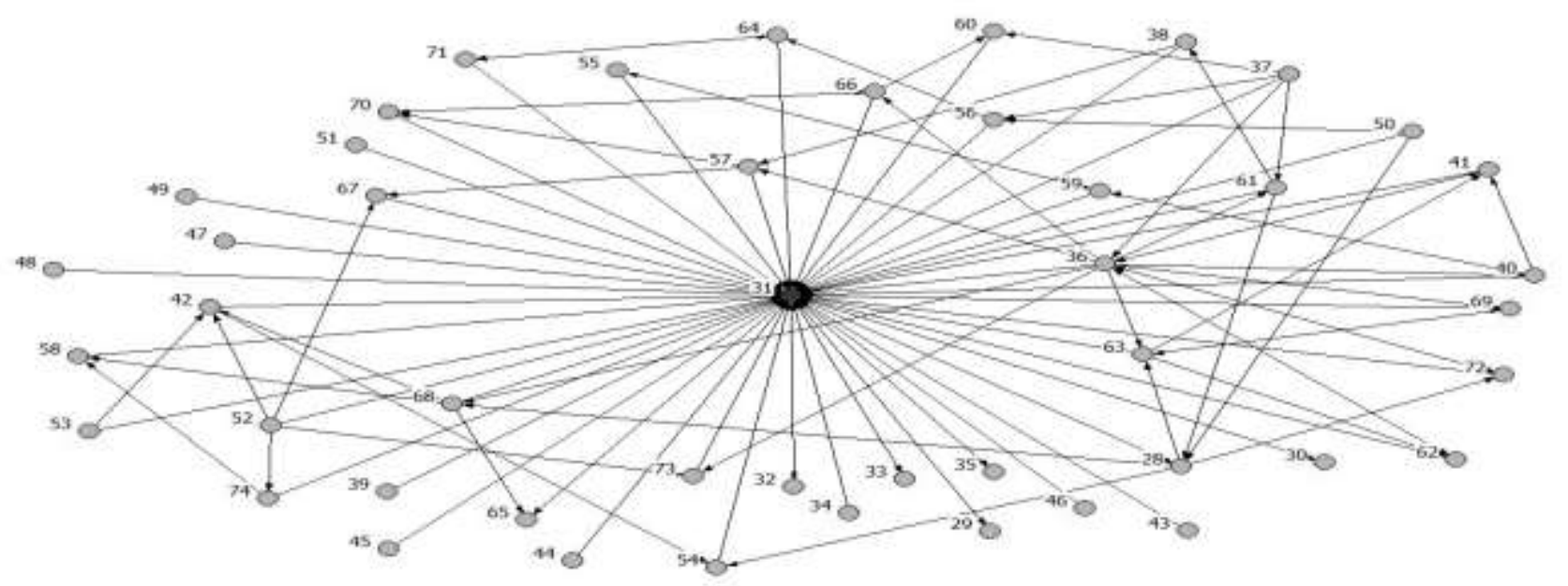

Gambar 2. Sosiogram Analisis Jaringan Komunikasi dalam Teknik Budi Daya Padi dengan Metode SRI pada Kelompok Tani Sumber Urip di Banyuwangi, 2018

Pada Gambar 2, aktor sentral dalam kelompok ini adalah aktor 31, yakni Bapak SAY. Bapak SAY merupakan ketua kelompok tani Sumber Urip yang sukses dalam menjalankan budi daya padi metode SRI. Beliau juga sering diminta menjadi pembicara dalam pelatihan atau seminar pertanian. Menurut Rogers dan Kincaid (1981), gambar struktur jaringan komunikasi seperti itu termasuk tipologi struktur interlocking personal network, yang merupakan jaringan komunikasi yang saling mengunci dan biasanya terdiri dari tautan-tautan homofili.

Jaringan komunikasi homofili terdiri dari individu yang saling berkomunikasi karena adanya kesamaan. Kesamaan ini didasari oleh kesamaan usia, jenis kelamin, pendidikan, prestise, kelas sosial, masa jabatan, dan pekerjaan. Temuan riset menunjukkan bahwa petani lebih senang berkomunikasi dengan petani lain yang sudah lama dikenalnya dan menjadi teman seperjuangannya dalam bercocok tanam padi. Selain itu, faktor lain yang memengaruhi preferensi komunikasi petani adalah kedekatan lokasi tempat tinggal dan adanya hubungan kekerabatan.

Lebih lanjut, menurut Devito (1997), struktur jaringan komunikasi yang terbentuk di kedua kelompok tani memiliki bentuk menyerupai struktur jaringan roda dan semua saluran (star). Struktur jaringan komunikasi berbentuk roda memiliki pemimpin yang jelas (posisi di tengah) yaitu aktor 1 dan aktor 31 . Hal ini membuat Bapak NYO sebagai aktor 1 menjadi satu-satunya anggota jaringan yang bisa mengirim dan menerima pesan ke semua anggota lain. Di samping itu, model semua saluran atau star merupakan model jaringan komunikasi yang mirip dengan lingkaran karena semua anggota memiliki peluang yang sama untuk memengaruhi orang lain. Di model ini, semua anggota memiliki peluang yang sama untuk berkomunikasi dengan anggota lainnya dan anggota juga menunjukkan tingkat partisipasi yang tinggi. Menurut Rogers dan Kincaid (1981), kelompok yang memiliki 
struktur jaringan komunikasi dengan pola semua saluran atau star tergolong ke dalam tipologi struktur interlocking personal network. Hal ini disebabkan oleh struktur jaringan komunikasi star yang saling mengunci satu sama lain.

Analisis jaringan komunikasi yang diukur dalam penelitian ini meliputi indeks in-degree centrality, out-degree centrality, kedekatan (closeness), dan betweenness. Tingkatan (degree) dalam analisis jaringan memperlihatkan popularitas aktor dalam jaringan sosial. Tingkatan (degree) adalah jumlah kontak dari dan ke aktor (Eriyanto, 2014). Lebih lanjut, Eriyanto (2014) menjelaskan bahwa dalam jaringan yang directed (mempunyai arah), degree ini bisa berupa in-degree (jumlah kontak yang mengarah ke aktor) dan out-degree (jumlah kontak yang keluar dari aktor). Angka indegree centrality, out-degree centrality, dan betweenness berada pada angka 0 hingga 1 , sedangkan closeness berada pada angka 0 hingga 100. Hasil penelitian menunjukkan bahwa nilai in-degree centrality tertinggi $(0,80)$ pada kelompok tani Sekar Arum ditunjukkan oleh aktor 1. Adapun nilai terendah $(0,00)$ diperlihatkan oleh aktor 11, 16, 17, 18, 20, 22, 24, 25.

Aktor 1 yaitu Bapak NYO merupakan ketua kelompok tani yang sudah lama menerapkan metode SRI sejak 6 tahun yang lalu sehingga memiliki banyak pengalaman. Selain itu, bapak NYO juga merupakan ketua kelompok tani yang cukup aktif di masyarakat. Beliau sering menghadiri pertemuan di balai desa dan berdiskusi dengan penyuluh pertanian sehingga menjadi tempat bertanya bagi petani lainnya. Bapak NYO juga menghasilkan produksi padi sebanyak 7-8 ton melalui metode SRI. Di samping itu, Bapak NYO juga dipandang sebagai sosok yang pandai, tegas dan bijaksana dalam memberikan solusi permasalahan anggota kelompoknya.

Hal tersebut membuat aktor 1 menjadi tempat bertanya di dalam jaringan komunikasi budi daya padi dengan metode SRI. Pada umumnya, materi pertanyaan mengenai budi daya padi dengan metode SRI meliputi perawatan padi seperti pengaturan air, pengendalian hama dan penyakit padi. Sementara itu, aktor yang memiliki tingkat indegree yang rendah pada umumnya termasuk kategori usia dewasa tengah, memiliki tingkat pendidikan yang tergolong rendah, pengalaman bertani dengan metode SRI yang tergolong rendah, dan memiliki luas lahan rata-rata di bawah dari 0,5 ha.

Pada kelompok tani Sumber Urip, nilai in-degree centrality tertinggi $(1,00)$ dipegang oleh aktor 31 sedangkan nilai terendah $(0,00)$ ditunjukkan oleh aktor 34, 37, 39, 43, 44, 45, 46, 47, 48, 49, 50, 51, 52, 53. Aktor 31 yaitu Bapak SAY, yang juga menjadi ketua Kelompok Tani Sumber Urip, merupakan petani yang sudah lama menerapkan metode SRI sejak pertama kali diadakan pelatihan. Selain itu, Bapak SAY juga sering kali diundang oleh Dinas Pertanian Kabupaten Banyuwangi untuk menjadi salah satu pembicara dalam seminar pertanian sebagai praktisi. Pengalaman mengikuti berbagai pelatihan dan menjadi pembicara membuat aktor 31 menjadi lebih kaya informasi dibandingkan anggota kelompok lainnya. Hal ini pulalah yang menyebabkan para anggota kelompok tani menjadikan aktor 31 sebagai tempat bertanya mengenai pembudidayaan padi dengan metode SRI. Sementara itu, nilai indegree centrality yang rendah ditunjukkan oleh petani dengan kategori usia dewasa tengah, dengan tingkat pendidikan yang tergolong rendah, tingkat pendidikan nonformal (dalam hal mengikuti pelatihan budi daya padi metode 
$\mathrm{SR})$ mayoritas rendah, dan luas lahan rata-rata 0,5-1 ha.

Selanjutnya, nilai out-degree centrality tertinggi $(0,31)$ pada kelompok tani Sekar Arum dipegang oleh aktor 23, dan nilai outdegree centrality terendah $(0,00)$ dipegang oleh aktor 11. Aktor 23 yaitu Bapak MSY merupakan anggota kelompok tani biasa yang aktif dalam menjalin kontak dengan anggota kelompok tani lainnya. Pada kelompok tani Sumber Urip, nilai out-degree centrality tertinggi $(0,26)$ ditunjukkan oleh aktor 36 , dan nilai out-degree centrality terendah $(0,02)$ diperlihatkan oleh aktor 29, 30, 32, 33, 34, 35, $39,43,44,45,46,47,48,49,51,54,58,60,65$, 67, 73. Aktor 36, yaitu Bapak PON, adalah salah satu pengurus di kelompok tani Sumber Urip yang membidangi pengolahan lahan.

Nilai betweenness tertinggi $(0,21)$ pada kelompok tani Sekar Arum dipegang oleh aktor 23, sedangkan pada kelompok tani Sumber Urip nilai tertinggi $(0,49)$ dipegang oleh aktor 31. Betweenness merupakan salah satu pengukuran sentralitas yang memperlihatkan posisi seorang aktor sebagai perantara dalam hubungan antaraktor di suatu jaringan (Eriyanto, 2014). Selanjutnya, nilai closeness tertinggi $(47,27)$ pada kelompok tani Sekar Arum dipegang oleh aktor 1, sedangkan pada kelompok tani Sumber Urip nilai tertinggi $(100,00)$ dipegang oleh aktor 31. Closeness atau kedekatan adalah salah satu pengukuran sentralitas yang menunjukkan seberapa dekat seorang aktor dengan seluruh aktor lain di dalam jaringan (Eriyanto, 2014). Adapun menurut Monge dan Contractor (2003), closeness atau kedekatan mengukur sejauh mana aktor secara langsung atau tidak langsung terhubung ke semua aktor lain dalam jaringan.
Budi daya padi dengan metode SRI pada penelitian ini mengacu pada pedoman Kementan RI (2014) yaitu penyemaian, pengolahan tanah, cara tanam, pengelolaan air, dan pengendalian hama serta gulma dengan metode organik. Penerapan budi daya padi dengan metode SRI pada kelompok tani Sekar Arum dan kelompok tani Sumber Urip dapat dilihat pada Tabel 2.

Tingkat penerapan budi daya padi metode SRI di kedua kelompok tani tergolong cukup baik sekalipun belum maksimal karena terdapat beberapa masalah di setiap tahapan penerapan metode SRI. Dibandingkan kelompok tani Sekar Arum, penerapan budi daya padi metode SRI di kelompok tani Sumber Urip masih lebih baik. Hal ini ditunjukkan dengan hasil panen padi kelompok tani Sumber Urip yang rata-rata mencapai 6-6.5 ton, sedangkan kelompok tani Sekar Arum rata-rata mencapai 3-5 ton.

Pada tahapan penyemaian, masih terdapat beberapa anggota yang kurang maksimal dalam melakukan penyemaian. Hal ini disebabkan karena masih terdapat beberapa anggota kelompok tani yang menanam bibit dengan umur bibit yang masih tergolong tua yaitu di atas 15 hari. Beberapa individu menanam padi dengan umur bibit yang mencapai 20 hari. Permasalahan lainnya meliputi kerepotan dalam melakukan pengujian benih dengan larutan air garam.

Menurut Handono (2013), salah satu kunci sukses dalam budi daya padi dengan metode SRI adalah penanaman bibit muda dengan umur 7-15 hari. Jika petani menanam bibit yang lebih tua, misalnya lebih dari 2-6 minggu, maka peluang untuk menghasilkan anakan tanaman akan lebih kecil. 
Tabel 2. Persentase Tingkat Penerapan Budi Daya Padi dengan Metode SRI di Kelompok Tani Sekar Arum dan Kelompok Tani Sumber Urip di Banyuwangi, 2018

\begin{tabular}{|c|c|c|}
\hline \multirow{2}{*}{ Penerapan budi daya padi metode SRI } & \multicolumn{2}{|c|}{ Persentase } \\
\hline & Sekar Arum & Sumber Urip \\
\hline \multicolumn{3}{|l|}{ Penyemaian } \\
\hline Rendah & 14,80 & 0,00 \\
\hline Sedang & 25,90 & 21,30 \\
\hline Tinggi & 59,30 & 78,70 \\
\hline Total & 100,00 & 100,00 \\
\hline \multicolumn{3}{|l|}{ Pengolahan tanah } \\
\hline Rendah & 3,70 & 2,10 \\
\hline Sedang & 18,50 & 0,00 \\
\hline Tinggi & 77,80 & 97,90 \\
\hline Total & 100,00 & 100,00 \\
\hline \multicolumn{3}{|l|}{ Cara tanam dan Jarak tanam } \\
\hline Rendah & 22,20 & 8,50 \\
\hline Sedang & 25,90 & 25,50 \\
\hline Tinggi & 51,90 & 66,00 \\
\hline Total & 100,00 & 100,00 \\
\hline \multicolumn{3}{|l|}{ Pengelolaan air } \\
\hline Rendah & 0,00 & 2,10 \\
\hline Sedang & 37,00 & 4,30 \\
\hline Tinggi & 63,00 & 93,60 \\
\hline Total & 100,00 & 100,0 \\
\hline \multicolumn{3}{|l|}{ Pengendalian hama dan gulma } \\
\hline Rendah & 3,70 & 0,00 \\
\hline Sedang & 59,30 & 14,90 \\
\hline Tinggi & 37,00 & 85,10 \\
\hline Total & 100,00 & 100,00 \\
\hline
\end{tabular}

Sumber: Data Diolah

Dapat dilihat dari tabel di atas bahwa penerapan budi daya padi dengan metode SRI dalam proses pengolahan tanah di kelompok tani Sekar Arum maupun kelompok tani Sumber Urip tergolong tinggi. Akan tetapi, masih terdapat beberapa anggota yang kurang maksimal dalam melakukan pengelolaan tanah. Hal ini disebabkan karena pencaplakan tidak selalu dilakukan mengingat kurangnya jumlah alat pencaplakan yang menyebabkan pencaplakan dilakukan secara bergilir. Masalah lainnya adalah masih digunakannya pestisida dan pupuk kimia dalam pengolahan tanah. Hal ini selaras dengan hasil penelitian Handono (2013) yang menyatakan bahwa para petani masih mengandalkan pupuk kimia untuk menyuburkan serta mempercepat pertumbuhan tanaman, terutama bagi tanaman padi yang perawatannya cenderung sensitif. Tabel di atas juga memperlihatkan bahwa tingkat penerapan cara tanam dan jarak tanam dalam budi daya padi metode SRI pada kedua kelompok tani tersebut tergolong tinggi. Akan tetapi, sebagian anggota lainnya berada pada kategori sedang dan rendah dalam tingkat penerapan cara tanam dan jarak tanam padi. Terdapat sebagian anggota kelompok yang tidak menerapkan jarak tanam yang tepat yaitu antara $25 \times 25 \mathrm{~cm}$ atau 30x30 cm dikarenakan kurangnya ketersediaan alat caplak. Permasalahan lainnya adalah hampir semua anggota memasukkan dua sampai tiga bibit padi per lubang. Hal tersebut mereka lakukan karena adanya "kul" atau keong yang biasa memakan bibit padi yang masih sangat muda. Hal ini membuat petani tidak berani mengambil risiko dengan hanya 
memasukkan satu bibit per lubang. Di samping itu, penanaman dengan posisi akar membentuk huruf "L" sulit diterapkan oleh buruh tanam yang dipekerjakan petani selama masa tanam padi. Permasalahan ini juga sering dialami oleh kedua kelompok tani. Seperti dijelaskan oleh Handono (2013), para petani atau buruh tanam kesulitan menanam dengan bibit muda. Penanaman bibit muda dengan cara mendorongnya ke dalam tanah dengan membentuk huruf "L" membuat buruh tanam kesulitan karena mereka tidak terbiasa. Buruh tanam terbiasa menanam bibit konvensional dengan cara ditekan ke dalam dengan kedalaman sekitar 4-6 cm, sehingga cara tanam bibit muda merupakan hambatan tersendiri bagi buruh tanam.

Selanjutnya, mayoritas anggota kedua kelompok tani telah menerapkan pengelolaan air sesuai dengan metode SRI. Namun demikian, masih terdapat beberapa anggota kelompok yang kurang maksimal dalam melakukan pengelolaan air. Hal ini disebabkan pemberian air yang tidak kontinyu pada saat padi berumur 7-41 hari. Metode SRI mengharuskan lahan tanam diberi air hingga becek selama 5 hari dan tergenang maksimal 3 $\mathrm{cm}$ selama 5 hari secara berselang-seling. Di kelompok tani Sekar Arum sebagian anggota hanya melakukan pemantauan air sesuai dengan turunnya hujan. Jika hujan tidak turun, sawah akan mereka beri air hingga dirasa cukup sedangkan apabila hujan, sawah tidak diairi. Selain masalah pengaturan jumlah air, pengendalian hama dan gulma pada kelompok tani Sumber Urip sudah baik, namun pada kelompok tani Sekar Arum tergolong sedang. Ada sebagian anggota kelompok yang belum sepenuhnya melakukan pengendalian hama dan gulma dengan metode SRI karena masih digunakannya pestisida anorganik meskipun barangkali jumlahnya tidak terlalu banyak. Hal ini selaras dengan hasil penelitian Handono (2013) yang menyatakan bahwa petani kesulitan mengendalikan hama dan penyakit tanaman secara terpadu.

Hubungan antara jaringan komunikasi dengan penerapan budi daya padi metode SRI dianalisis dengan uji korelasi Pearson sebagaimana tampak pada Tabel 3. Tabel 3 menunjukkan hasil uji korelasi Pearson antara out-degree centrality dengan penerapan budi daya padi metode SRI sebesar $-0,415^{\text {×x }}$ dengan derajat hubungan korelasi yang sedang. Hal ini menunjukkan bahwa terdapat korelasi yang nyata dan negatif antara out-degree centrality dengan penerapan budi daya padi metode SRI. Semakin rendah nilai out-degree centrality maka nilai penerapan budi daya padi metode SRI tinggi. Sebaliknya, semakin tinggi nilai out-degree centrality maka nilai penerapan budi daya padi metode SRI rendah.

Hal ini berbeda dengan hasil penelitian yang dilakukan oleh Cindoswari (2012) dan Zulkarnain (2015) yang memasukkan in-degree centrality dan out-degree centrality ke dalam sentralitas lokal. Hasil penelitian yang dilakukan oleh Cindoswari (2012) dan Zulkarnain (2015) menunjukkan bahwa terdapat hubungan yang nyata dan positif antara sentralitas lokal dengan adopsi teknologi di dalam kelompok. Artinya, semakin banyak petani yang terhubung dengan individu lain dalam lingkungan terdekat akan semakin tinggi pula tingkat adopsi teknologi yang diterapkan. 
Tabel 3. Nilai Koefisien Korelasi Pearson antara Jaringan Komunikasi dengan Penerapan Budi Daya Padi Metode SRI

\begin{tabular}{lc}
\hline \multicolumn{1}{c}{ Jaringan komunikasi } & Penerapan budi daya padi metode SRI \\
\hline In-degree centrality & 0,100 \\
Out-degree centrality & $-0,415^{\times \times}$ \\
Closeness & $0,564^{\times \times}$ \\
Betweenness & $-0,040$ \\
\hline
\end{tabular}
Keterangan: ${ }^{\star \star}$ Korelasi signifikan pada tingkat 0,01 (2-tailed).

Temuan riset menunjukkan bahwa anggota di kedua kelompok tani sudah lama mendapatkan pelatihan budi daya padi dengan metode SRI dan setiap anggota kelompok tani telah mengetahui dan memahami metode SRI dalam budi daya padi dengan baik. Pada umumnya, anggota kelompok tani tidak terlalu banyak menjalin kontak dengan anggota lainnya. Hal ini terjadi karena jaringan komunikasi di kedua kelompok cenderung memusat hanya ke beberapa aktor yang menjadi aktor sentral dalam jaringan komunikasi. Di samping itu, setiap anggota kelompok tani telah menerima informasi tentang budi daya padi metode SRI dengan baik sejak awal. Jadi, saat penelitian dilakukan, para anggota kelompok tani tidak banyak menjalin kontak untuk bertanya tentang penerapan budi daya padi metode SRI. Hal ini menyebabkan rendahnya nilai out-degree centrality dan tingginya tingkat penerapan metode SRI.

Selanjutnya, Tabel 3 menunjukkan hasil uji korelasi Pearson antara closeness (kedekatan) dengan penerapan metode SRI sebesar $0,564^{\times x}$ dengan derajat hubungan korelasi sedang. Hal ini berarti bahwa terdapat hubungan yang nyata dan positif antara closeness dengan penerapan metode SRI. Semakin tinggi nilai closeness, maka nilai penerapan metode SRI juga tinggi. Jadi, semakin tinggi tingkat kedekatan anggota kelompok tani dengan anggota kelompok tani lainnya di dalam jaringan, semakin baik pula penerapan budi daya padi metode SRI yang dilakukan. Anggota yang mempunyai closeness yang baik hanya membutuhkan satu atau beberapa langkah agar bisa terhubung dengan anggota lainnya. Semakin tinggi tingkat closeness, maka semakin tinggi juga tingkat kemudahan dan kebebasan seorang anggota kelompok tani untuk mengakses informasi budi daya padi metode SRI. Hal ini selaras dengan hasil penelitian Cindoswari (2012) yang mengukur closeness dengan konsep sentralitas global. Hasil penelitian tersebut menunjukkan bahwa terdapat hubungan yang nyata antara kedekatan dengan tingkat penerapan teknologi produksi ubi kayu. Penelitiannya menunjukkan bahwa semakin mudah bagi seseorang untuk menghubungi semua individu, maka semakin tinggi tingkat penerapan teknologi produksi yang dilakukan oleh petani ubi kayu.

\section{KESIMPULAN DAN SARAN}

Hasil penelitian ini menunjukkan bahwa jika mengacu pada struktur jaringan menurut Rogers dan Kincaid (1981), kelompok tani Sekar Arum dan kelompok tani Sumber Urip memiliki struktur jaringan interlocking personal network. Di samping itu, jika mengacu pada Devito (1997) struktur jaringan yang terbentuk tergolong pada struktur jaringan roda dan semua saluran (star). Hal ini menandakan bahwa terdapat aktor-aktor sentral di dalam jaringan komunikasi budi daya padi metode SRI. Aktor-aktor sentral inilah yang menjadi sumber informasi atau tempat bertanya mengenai budi daya padi metode SRI. Jaringan 
komunikasi interlocking personal network di dalam kelompok tani Sekar Arum maupun Sumber Urip terbentuk karena interaksi dan komunikasi berbasis kesamaan dengan orang lain. Kesamaan-kesamaan itu antara lain lama pengalaman bertani padi, kedekatan lokasi tempat tinggal, dan adanya hubungan kekerabatan.

Selanjutnya, penelitian ini juga menunjukkan bahwa terdapat hubungan antara jaringan komunikasi dengan tingkat penerapan budi daya padi dengan metode SRI. Dalam hal ini, terdapat hubungan yang nyata antara outdegree centrality dan closeness (kedekatan) dalam penerapan budi daya padi metode SRI. Out-degree centrality memiliki hubungan yang nyata dan negatif dengan penerapan budi daya padi metode SRI, sedangkan closeness memiliki hubungan yang nyata dan positif dengan penerapan budi daya padi metode SRI.

Tingkat penerapan budi daya padi dengan metode SRI di kelompok tani Sekar Arum maupun di kelompok tani Sumber Urip masih belum maksimal. Oleh karena itu, diperlukan peningkatan kapabilitas aktor sentral dalam jaringan untuk memperkaya informasi tentang budi daya padi metode SRI di kelompok tani. Selain itu, dibutuhkan pula perhatian dari Dinas Pertanian Kabupaten Banyuwangi dan pihak penyuluh pertanian untuk menambah jumlah alat pertanian dan mencarikan solusi terkait kurang maksimalnya penerapan budi daya padi metode SRI. Di samping itu, penting pula dilakukan peningkatan pemahaman kepada setiap anggota kelompok tani dalam penerapan budi daya padi dengan metode SRI yang mengharuskan adanya suatu sinergi dalam budi daya padi metode SRI. Sinergitas dalam budi daya padi metode SRI dalam hal ini berarti bahwa setiap perlakuan atau tindakan dalam penyemaian, pengolahan tanah, cara tanam dan jarak tanam, pengaturan air, pengendalian hama dan gulma akan saling memengaruhi dalam memperoleh hasil yang maksimal. Berdasarkan hal tersebut, disarankan agar pemangku kepentingan dapat merumuskan strategi pengembangan di bidang budi daya padi dengan metode SRI berbasis kearifan lokal.

\section{UCAPAN TERIMA KASIH}

Penulis menyampaikan ucapan terima kasih kepada kepala desa beserta staf dari Desa Watukebo, Kecamatan Rogojampi dan Desa Sumber Agung, Kecamatan Pesanggaran, Kabupaten Banyuwangi yang telah membantu penulis dalam mengumpulkan data. Penulis juga menyampaikan ucapan terima kasih kepada ketua kelompok tani Sekar Arum dan Sumber Urip serta anggota kelompok tani yang terhimpun di dalamnya yang telah membantu penulis dalam mendapatkan data. Ucapan terima kasih juga penulis sampaikan kepada semua pihak yang telah membantu pelaksanaan penelitian ini, semoga selalu diberkati.

\section{DAFTAR PUSTAKA}

Adawiyah, C. R., Sumardjo, \& Mulyani, E. S. (2017). Faktor-Faktor yang Memengaruhi Peran Komunikasi Kelompok Tani Dalam Adopsi Teknologi Upaya Khusus (Padi, Jagung, Dan Kedelai) di Jawa Timur. Jurnal Agro Ekonomi, 35(2), 151-170. http://dx.doi.org/10.21082/jae.v35n2.201 7.151-170

Anugrah, I. S., Sumedi, \& Wardana, I. P. (2008). Gagasan dan Implementasi System of Rice Intensification (SRI) dalam Kegiatan Budi Daya Padi Ekologis (BPE). Analisis Kebijakan Pertanian, 06(01), 75-99. http://dx.doi. org/10.21082/akp.v6n1.2008.75-99. 
Cindoswari, A. R. (2012). Jaringan Komunikasi Dalam Penerapan Teknologi Produksi Ubi Kayu (Kasus Petani Ubi Kayu di Desa Suko Binangun, Kecamatan Way Seputih, Kabupaten Lampung Tengah, Provinsi Lampung). Tesis, Fakultas Ekologi Manusia, Bogor: Institut Pertanian Bogor.

Devito, J. A. (1997). Human Communication: The Basic Course. New York: Longman. Eriyanto. (2014). Analisis Jaringan Komunikasi: Strategi Baru dalam Penelitian Ilmu Komunikasi dan Ilmu Sosial Lainnya. Jakarta: Prenadamedia Group.

Fitrianto, R. (2018). Kerusakan Tanah Ancaman Bagi Pertanian Indonesia. Diakses pada tanggal: 14 Januari 2019 dari: https://sawitindonesia.com/kerusak an-tanah-ancaman-bagi-pertanianindonesia/

Gunawan, I. (2017). Jaringan Komunikasi Pelaku Agribisnis Ikan Kolam Air Deras di Kecamatan Caringin Kabupaten Bogor. Tesis, Fakultas Ekologi Manusia, Bogor: Institut Pertanian Bogor.

Handono, S. Y. (2013). Hambatan dan Tantangan Penerapan Padi Metode SRI (System of Rice Intensification). Jurnal Habitat, XXIV(1), 11-21. http://habitat. ub.ac.id/index.php/habitat/article/view/9 7

Hertanto, D., Sugiyanto, \& Safitri, R. (2016). Analisis Struktur Jaringan Komunikasi dan Peran Aktor dalam Penerapan Teknologi Budidaya Kentang (petani Kentang Desa Ngantru Kecamatan Ngantang Kabupaten Malang). Jurnal Habitat, 27(2), 55-65. https://doi.org/ 10.21776/ub.habitat.2016.027.2.7

Kementan RI. (n.d.). Sektor Pertanian
Berkontribusi Positif Terhadap Pertumbuhan Ekonomi RI Triwulan II 2017. Diakses pada tanggal 20 Desember 2018 dari https://bit.ly/2pSFeJC

Kementan RI. (2014). Pedoman Teknis Pengembangan System of Rice Intensification TA. 2014. Jakarta: Direktorat Perluasan dan Pengelolaan Lahan. Kementrian Pertanian. https://bit.ly/2ADxsFK

Kementan RI. (2015). Renstra Kementrian Pertanian Pertanian Tahun 2015-2019. Jakarta: Biro Perencanaan. Kementrian Pertanian. http://www1.pertanian.go.id/ file/RENSTRA_2015-2019.pdf

Mediani, M. (2018). Lahan Kritis Indonesia 14 Juta Ha, Pemerintah Kewalahan. Diakses pada tanggal: 14 Januari 2019 dari: https://bit.ly/33prKCV

Monge, P., \& Contractor, N. (2003). Theories of Communication Networks. New York: Oxford University Press.

Rogers, E. M. (1983). Diffusion of Innovations, Third Edition. New York: The Free Press. Rogers, E. M., \& Kincaid, D. L. (1981). Communication Networks: Toward A New Paradigm for Research. New York: The Free Press.

Soekartawi. (2005). Prinsip Dasar Komunikasi Pertanian. Jakarta: UI Press.

Toesland, R., Jones, L., \& Gellis, Z. (2004). Group Dynamics. New York: Guilford Publication.

Zulkarnain. (2015). Analisis Hubungan Jaringan Komunikasi Dengan Perubahan Taraf Penghidupan Dan Pola Pikir Dalam Pemberdayaan Pembudidaya Ikan Di Kabupaten Kampar, Riau. Disertasi, Fakultas Ekologi Manusia, Bogor: Institut Pertanian Bogor. 